\title{
Role of water/rock interaction in the formation of ore-bearing solutions and deposition of hydrothermal ore, Sadon Mining District, North Caucasus Mountains, Russia
}

\author{
Michael Borisov ${ }^{1, *}$, Dmitry Bychkov ${ }^{1}$, Mariya Volkova $^{1}$, and Yury Shvarov ${ }^{1}$ \\ ${ }^{1}$ Lomonosov Moscow State University, Faculty of Geology, Moscow, 119234 Russia
}

\begin{abstract}
REE distribution patterns of the ores and host rocks of the Dzhimidon vein lead-zinc deposit (North Caucasus, Ossetia, Sadon mining district, Russia) have been analyzed to elucidate the source(s) of hydrothermal ore deposits. Two types of prevailing rocks are involved in ore formation - Paleozoic granites (the main ore-hosting rocks at the majority of deposits) and Precambrian schists (specific only the for host rocks of the Dzhimidon deposit). The source of ore components tends to be complex and includes host rocks in variable proportions that could be characterized by REE distribution in ores. Interaction of water with combined sources was thermodynamically modeled. Critical differences were found in the oreforming models, with variable sequence and rock proportions during interaction with barren fluid.
\end{abstract}

\section{Introduction}

The determination of fluid sources is a fundamental problem in interpreting formation of hydrothermal ore deposits. One of the sources, which could completely provide the components of many types of hydrothermal deposits, is the local bedrock of the deposit area. These rocks could be the host rocks for ore bodies or located at some distance from them. There is a broad literature that supports the significant role of mobilization of ore components from diverse sources.

One approach to studying the origin of hydrothermal ore deposits combines geochemical study and thermodynamic modeling. Geochemical methods examine ore-forming elements and the distribution of rare earth elements (REE) in cross-sections of veins and in the adjacent host-rock. Methods used include X-ray fluorescence (XRF), atomicabsorption spectroscopy (AAS), inductively-coupled plasma mass spectrometry (ICP-MS). Thermodynamic modeling is a development of quantitative thermodynamic models of ore formation and their further analysis including estimation of ore-bearing fluid and ore formation zones. Geochemical data are required for thermodynamic modeling and for verification of the results.

$\mathrm{Pb}-\mathrm{Zn}$ deposits of the Sadon Ore District in the North Ossetia region of Russia were chosen for this study. Possible sources of components for hydrothermal vein lead-zinc deposits of the Sadon ore district are the Paleozoic granites, formed during pre-Callovian time $\left(\mathrm{J}_{2}\right)$, which host most of the ore veins. This conclusion was first reported by Turgarinov et al. [1], on the basis of identical $\mathrm{Pb}$ isotope compositions of galena from 11 deposits of North Ossetia and K-feldspars from magmatic and metamorphic rocks of the area. It was concluded that... "direct sources of the lead at the deposits were Paleozoic granitoids," while "extraction of lead was related to the metasomatic reworking of feldspathic component of the granitoids" in the Middle Jurassic. This conclusion is supported by our data on the distribution of trace ore elements in the primary dispersion aureoles at different horizons of the Kholst, Arkhon, Zgid, and Dzhimidon deposits, as well as by the results of thermodynamic modeling of ore mobilization and ore formation [2, 3].

The following geological model of hydrothermal system was developed for these deposits [3]. Carbonated-chloride waters circulated in the pre-ore time within the Sadon-Unal deep-seated normal fault bounding the deposit area to the south. The emplacement of dikes and stocks and intense tectonic movements triggered hydrothermal processes during the Middle Jurassic, with intrusive bodies provided the required heat source, whilst NW- and NE-trending orecontrolling tension-shear fractures, formed a decompaction zone. Heated solutions from the Sadon-Unal normal fault penetrated through decompaction zone in the Paleozoic granites (and in other rocks) and interacted with them. These processes led to the formation of mobilization zone of diverse components, including ore metals and sulphide sulfur. The mobilization zone is the space where the reaction takes place between the rocks and the barren solution and the orebearing solution is formed. This zone was confined to the junction zone of the deep-seated fault and subsidiary fractures. Ore-bearing solutions from mobilization zone moved upward along ore-controlling fractures. Gradual cooling of ore-bearing solutions through heat exchange with colder host rocks and heat loss in the course of local

\footnotetext{
* Corresponding author: borisov@geol.msu.ru
} 
heterogenization led to the formation of base-metal filling veins and aureoles around them. Hydrothermal veining was simulated in accordance with this geological model and the results are discussed in this paper.

\section{REE distribution in ores and host rocks as indictor of the ore sources of base- metal veins}

Most of the deposits of this district (Zgid, Sadon, Arkhon, and others) are situated among Paleozoic granites, and only ore veins of the Dzhimidon deposit are mainly confined to metamorphic rocks of the Buron Formation $\left(\mathrm{PR}_{3}-\mathrm{PZ}_{1}\right)$. Paleozoic granites underlie these rocks through low-angle faults, but their exposures are absent within ore bodies examined.

In this work, the sources of ore components were estimated based on REE distribution in ores and host rocks of the Dzhimidon deposit. The data were obtained for 27 ore samples from 12 cross-sections (full vein cross-sections sampled in 2 to $5 \mathrm{~cm}$ intervals) along the Tsentral noye, Osnovnoye and Tsagarsar ore bodies (adit numbers 47 and 49 , Dzhimidon middle horizons) and for 10 host rocks of the area.

The total REE content in the base-metal veins is lower than in the host rocks, varying from 2 to $52 \mathrm{ppm}$. The REE contents for a set of diverse samples from the Paleozoic granites vary from 54 to 213 ppm, with the maximum REE content of 198 ppm observed in the mica schist, while quartz-chlorite-epidote and quartz-chlorite-albite schists are characterized by REE content as low as 127 and 83 ppm, respectively. Two granite porphyry samples have similar REE concentrations (104 and 127 ppm), whereas Jurassic volcanogenic rocks and a dacitic andesite dike contain 120 and 121 ppm REE, respectively. All ore bodies studied are situated at the horizons of adit numbers 47 and 49 only within the Precambrian crystalline schists characterized by the absence of an Eu anomaly $(\mathrm{Eu} / \mathrm{Eu} *=1$; the value of Eu anomaly $\left(\mathrm{Eu} / \mathrm{Eu}^{*}\right)$ is calculated from $\left.\mathrm{Eu}_{N} /\left(\sqrt{ } \mathrm{Sm}_{N} * \mathrm{Gd}_{N}\right)\right)$ and a low $\mathrm{La} / \mathrm{Yb}$ ratio. Distinct Eu negative anomalies and high La/Yb ratios are observed in granites.

In terms of Eu/Eu* and $\mathrm{La}_{N} / \mathrm{Yb}_{N}$ ratio, ore samples may be subdivided into three groups: (1) Eu/Eu* is close to 1 and low $\mathrm{La}_{N} / \mathrm{Yb}_{N}$ ratio (Fig. 1a); (2) mean values of both Eu/Eu* and $\mathrm{La}_{N} / \mathrm{Yb}_{N}$ (Fig. 1b); (3) distinct Eu negative anomaly and high $\mathrm{La}_{N} / \mathrm{Yb}_{N}$ ratio (Fig. 1c). REE patterns of some ore samples correspond to REE patterns of either Paleozoic granites or Precambrian schists (Fig. 1a, 1c), however REE patterns of most ore samples indicate a combined/complex source for ore components.
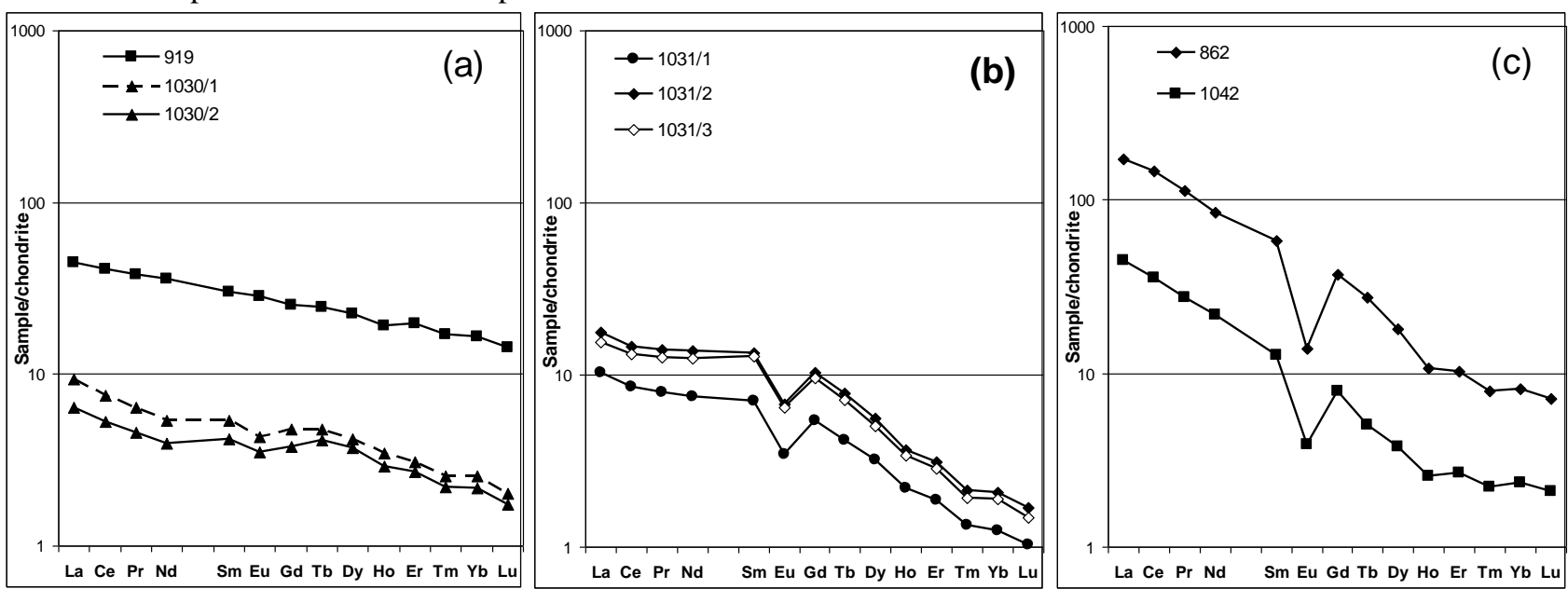

Fig. 1. Chondrite-normalized REE distribution patterns in ore samples (adit numbers 49 and 47) and in host rocks of the Dzhimidon deposit (sample numbers shown): (a) samples with $\mathrm{Eu} / \mathrm{Eu}^{*}$ close to 1 and low $\mathrm{La}_{N} / \mathrm{Yb}_{N}$ ratio (№1030/1, 1030/2) versus quartzchlorite-epidote schist (№919, PR $3-\mathrm{PZ}_{1}$ ); (b) ore samples with mean values of both Eu/Eu* and $\mathrm{La}_{N} / \mathrm{Yb}_{N}$ (№1031/1-1031/3), (c) ore sample with distinct Eu anomaly and high $\mathrm{La}_{N} / \mathrm{Yb}_{N}$ ratio (№1042) versus Paleozoic granite (№862, $\mathrm{PZ} 3$ ).

A pattern emerges from these data as illustrated in Fig. 2, which demonstrates mixing between crystalline schist (no. 919) and granites (nos. 862, 1066, 1081). Mixing was calculated for $\mathrm{Eu} / \mathrm{Eu}^{*}$ and $\mathrm{La}_{N} / \mathrm{Yb}_{N}$ ratios with a step of $10 \%$. It is seen that 17 ore samples in this diagram fall on a general trend from crystalline schist to Paleozoic granite or Jurassic granite porphyry (arrow A).

The formation of intervals of ore veins, represented by 17 ore samples, is thought to be caused by variable interaction of hydrothermal solutions with Paleozoic granites and metamorphic rocks which probably served as the main sources of REE and ore components in the base-metal veins. REE patterns of seven samples are shifted from trend A toward the higher $\mathrm{La}_{N} / \mathrm{Yb}_{N}$ or $\mathrm{Eu} / \mathrm{Eu} *$ ratios. This trend in the REE patterns of ore samples possibly reflects the contribution of ore components from an additional source, for instance, Jurassic volcanogenic rocks. The possible trend of this contribution is shown by dashed arrow B in Fig. 2. 


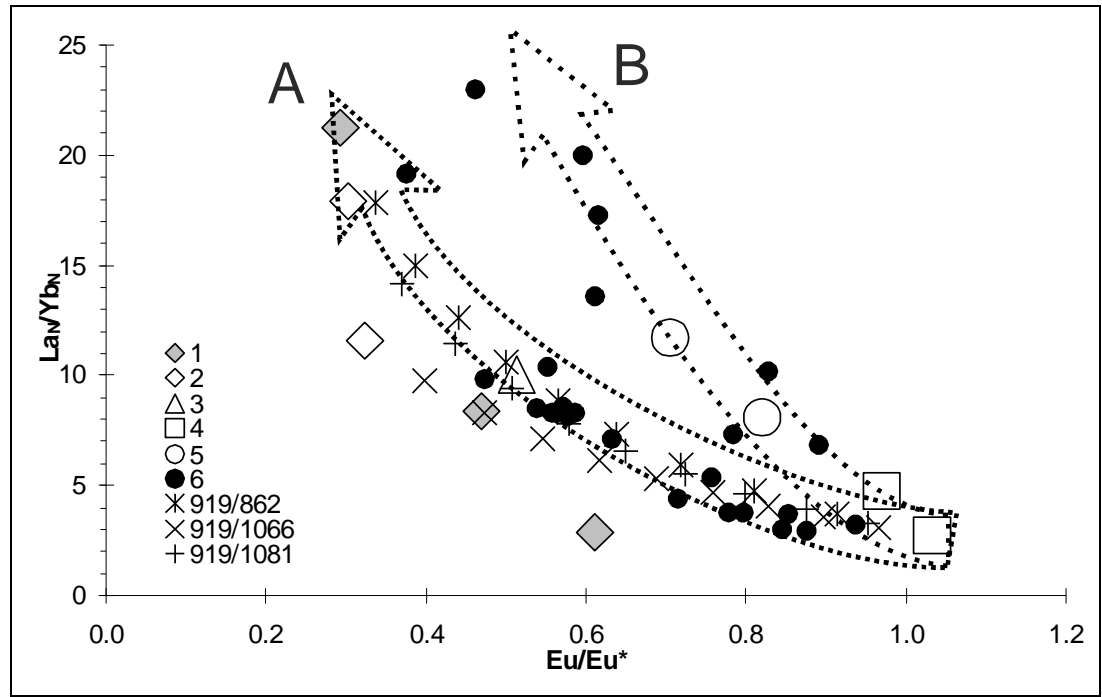

Fig. 2. Characteristics of REE patterns in ore samples, host rocks, and "granite-crystalline schist" mixture (Legend: 1 - granite (PZ); 2 - granite-porphyry $\left(\mathrm{J}_{2}\right) ; 3$ - mica schist $\left(\mathrm{PR}_{3}-\mathrm{PZ} \mathrm{Z}_{1}\right) ; 4$ - crystalline schist $\left(\mathrm{PR}_{3}-\mathrm{PZ} \mathrm{Z}_{1}\right) ; 5$ - dacitic andesite dike $\left(\mathrm{J}_{2}\right)$ and andesitic volcanic rock $\left(\mathrm{J}_{1}\right) ; 6$ - ore samples. Mixing patterns (symbols are shown each 10\% from one to another rock): 919/862 - mixing between Paleozoic granite and crystalline schist (trend is shown by dashed arrow A); 919/1066 and 919/1081 - mixing of graniteporphyry and crystalline schist). Dashed arrow B shows inferred change of characteristics of ore samples due to additional effect of Jurassic volcanogenic rocks.

Thus, both types of prevailing rocks, namely Paleozoic granites and Precambrian schists, were involved in the hydrothermal veining in Jurassic time. The source of ore components is likely to have been complex and includes host rocks in variable proportions which could be characterized by REE distribution in ores (Fig. 2). Thermodynamic models were developed based on these data.

\section{Thermodynamic modeling of base-metal veining with a complex source of ore components}

Thermodynamic models allowed variable combinations host rock sources involved in the formation of base-metal ore to be estimated for the compositional system H-O-K-Na-Ca-Mg-Al-Si-Fe-C-Cl-S-Zn-Pb-Cu (HCh package [5, 6],). The structure of the models is illustrated in Fig.3.

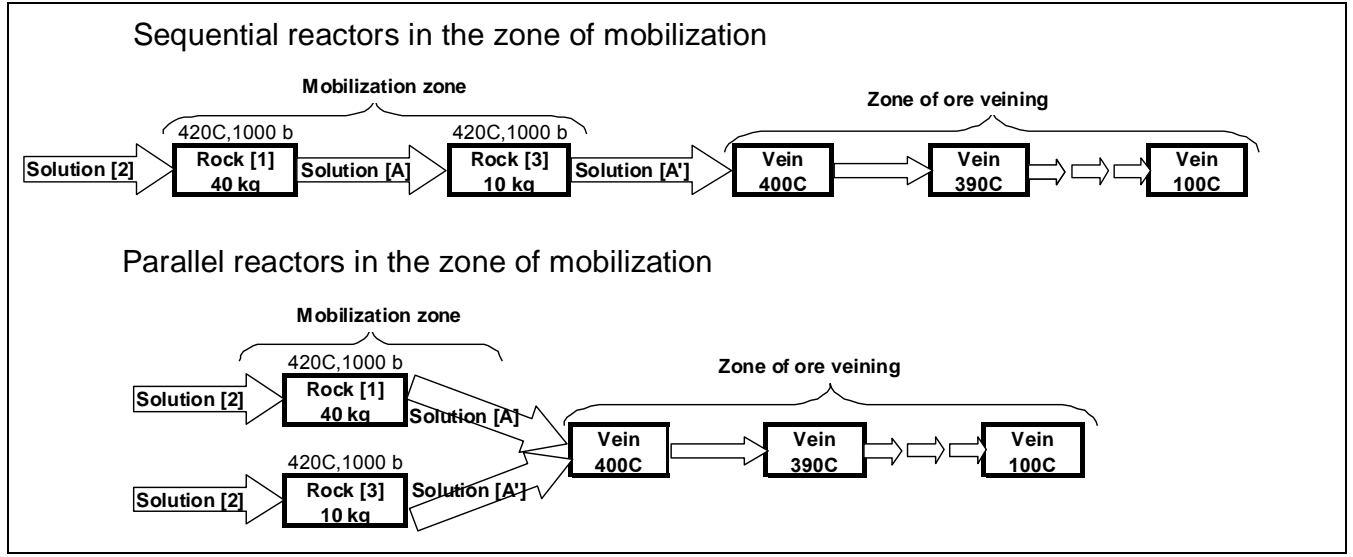

Fig. 3. Schematic diagram of the thermodynamic modeling.

As illustrated in (Fig.3), the principal parts of the model are: (i) the mobilization zone, i.e. the reaction of variable combinations of rocks (sequential or parallel reactors) containing equal concentrations of $\mathrm{Zn}, \mathrm{Pb}, \mathrm{Cu}$, and sulphide sulfur with 50 portions of barren fluid $\left(1 \mathrm{~m} \mathrm{NaCl}, 0.5 \mathrm{~m} \mathrm{H}_{2} \mathrm{CO}_{3}, 1 \mathrm{~kg} \mathrm{H} \mathrm{H}_{2} \mathrm{O}\right.$ ) at $420^{\circ} \mathrm{C}$ and $1 \mathrm{kbar}$; and (ii) the zone of ore veining is 31 consecutive flow reactors describing the vein with temperature decreasing from $400^{\circ} \mathrm{C}$ to $100^{\circ} \mathrm{C}$ with a step of $10^{\circ} \mathrm{C}$ at $1 \mathrm{kbar}$. The ore-bearing solution, after leaving the mobilization zone, forms the vein $(50$ subsequent waves or $\mathrm{W})$. Based upon previous thermodynamic results $[2$, it was concluded that such $\mathrm{T}$ and $\mathrm{P}$ in the mobilization zone cause the formation of modeled veins, with bulk and local $\mathrm{Zn}$ concentration about $30 \%$ and more than $60-70 \%$ (in the cross-section of veins), respectively. The layer mechanism describes the precipitation of solid phases in the vein (minerals precipitated from each portion of solution do not react with the subsequent portions, i.e. separate layers are overgrown) [2,3]. 
The system of sequential reactors in the mobilization zone was calculated for several host rock ratios: $20 \%$ of crystalline schist (CD) in the first reactor and $80 \%$ of granite (Y) in the second one with water/rock ratios that varied from 10 to 40 , respectively (shown on plots as "20\% CD $\rightarrow 80 \% \mathrm{Y}$ "); $80 \% \mathrm{CD}$ in the first reactor and $20 \% \mathrm{Y}$ in the second one with water/rock ratios of 40 to 10 (the results for both cases are shown on the left-hand plots, Fig. 4); 80\% Y in the first reactor and $20 \% \mathrm{CD}$ in the second one with water/rock ratios 40 to 10 , respectively; $20 \% \mathrm{Y}$ in the first reactor and $80 \% \mathrm{CD}$ in the second one with water/rocks of 10 and 40 (the results for both cases are shown on the righthand plots of Fig. 4).
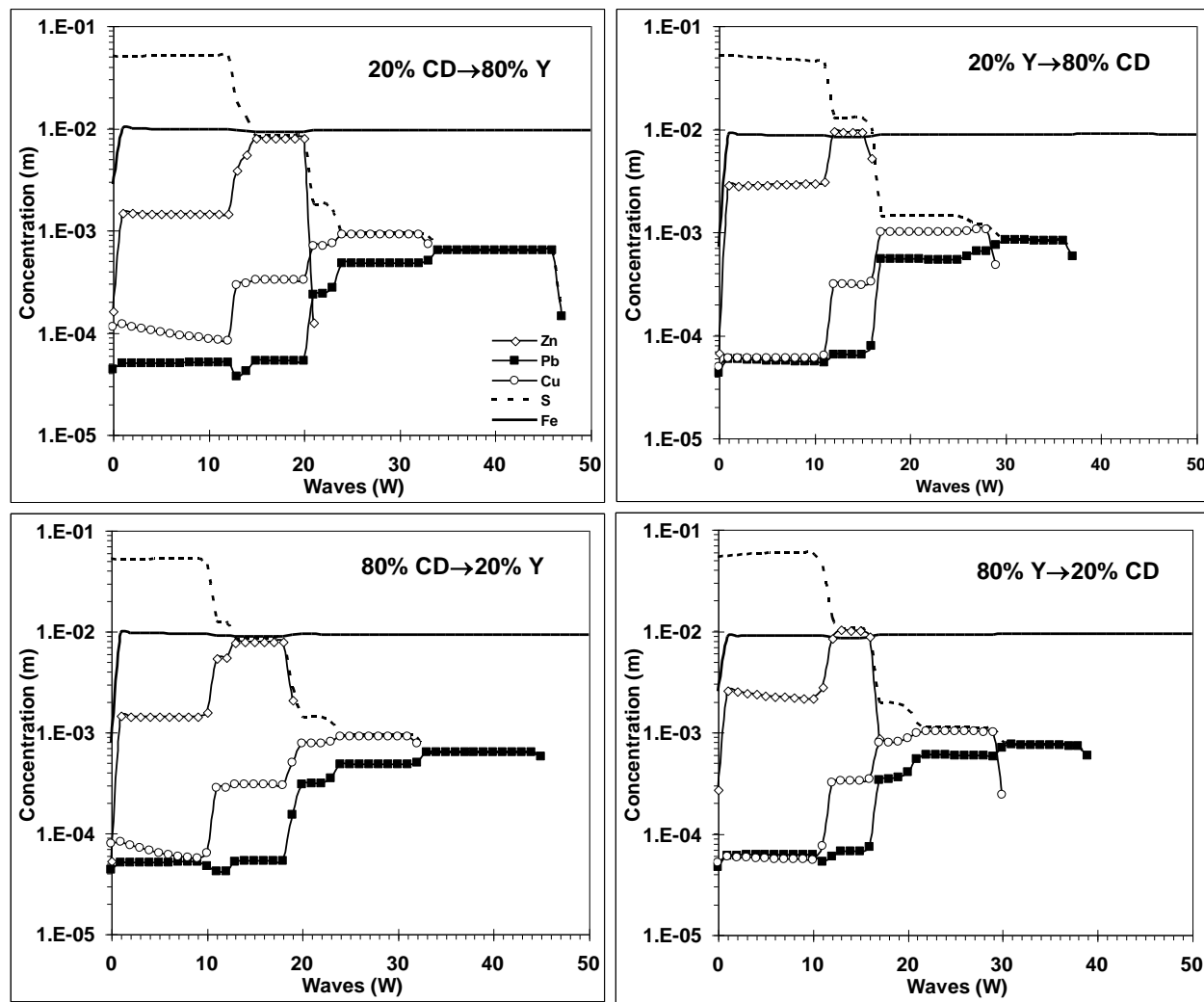

Fig. 4. Composition of ore-bearing fluids resulted from consequent reaction of barren fluid and variable combinations of host rocks in mobilization zone.

The ore components are mobilized in the same way in all four cases. However, there are some distinctions: (i) different "time" of complete leaching of ore elements (45 and more W for left-hand plots and 35-40 W for the righthand plots); (ii) pyrrhotite (for left-hand plots where mobilization process is completed by the interaction with granite) or pyrite (for right-hand plots with the schist at the end) is stable iron sulfide; and (iii) remarkable differences in ore component concentrations (especially for $\mathrm{Zn}$ ). Obviously, the mineralogy of altered granite and crystalline schist is different (initially these are felsic and mafic rocks, respectively). Increased concentration of ore components in the mobilization zone with crystalline schist as final rock and stable pyrite, results in a shortened "time" period (W in our case) of complete leaching.

These differences in the mobilization zone alter the mineralogy filling veins in the model results. Fig. 5 shows modeling results for sequence and rate of ore mineral precipitation in veins at one of the updip levels corresponding to $200^{\circ} \mathrm{C}$. A temperature range of 150 to $200^{\circ} \mathrm{C}$ is consistent with the strongest sphalerite and galena deposition. The early mineral assemblage, near-contact area of the vein or first layers, contains three times more pyrite than sphalerite (50$60 \%$ pyrite, up to $20 \%$ sphalerite), followed by a monosphalerite layer (up to $60 \%$ sphalerite) that is precipitated from the ore-bearing fluid from its consequent reaction with "crystalline schist $\rightarrow$ granite" (left-hand plots in Fig. 5). Monosphalerite layers are typical of these deposits. An early mineral assemblage containing a little more pyrite than sphalerite (40\% pyrite, up to $30 \%$ sphalerite) was followed by monosphalerite layer precipitated from ore-bearing fluid resulting from consequent reaction with "granite $\rightarrow$ crystalline schist" (right-hand plots in Fig. 5) with lower proportion of $\mathrm{CD}$ only; the higher proportion of $\mathrm{CD}$ in the mobilization zone does not lead to formation of monosphalerite layer, which is only formed $150^{\circ} \mathrm{C}$ in the $20 \% \mathrm{CD} \rightarrow 80 \% \mathrm{Y}$ model. Pyrrhotite, which is it is typical of all deposits in the area, is precipitated at lower zones of higher temperature in the " $\mathrm{CD} \rightarrow \mathrm{Y}$ " model. By contrast, pyrrhotite is not precipitated at higher temperature zones in "Y $\rightarrow C D$ " model, with pyrite dominating updip in the vein. This model results in decrease of maximum bulk content of pyrite in veins. 

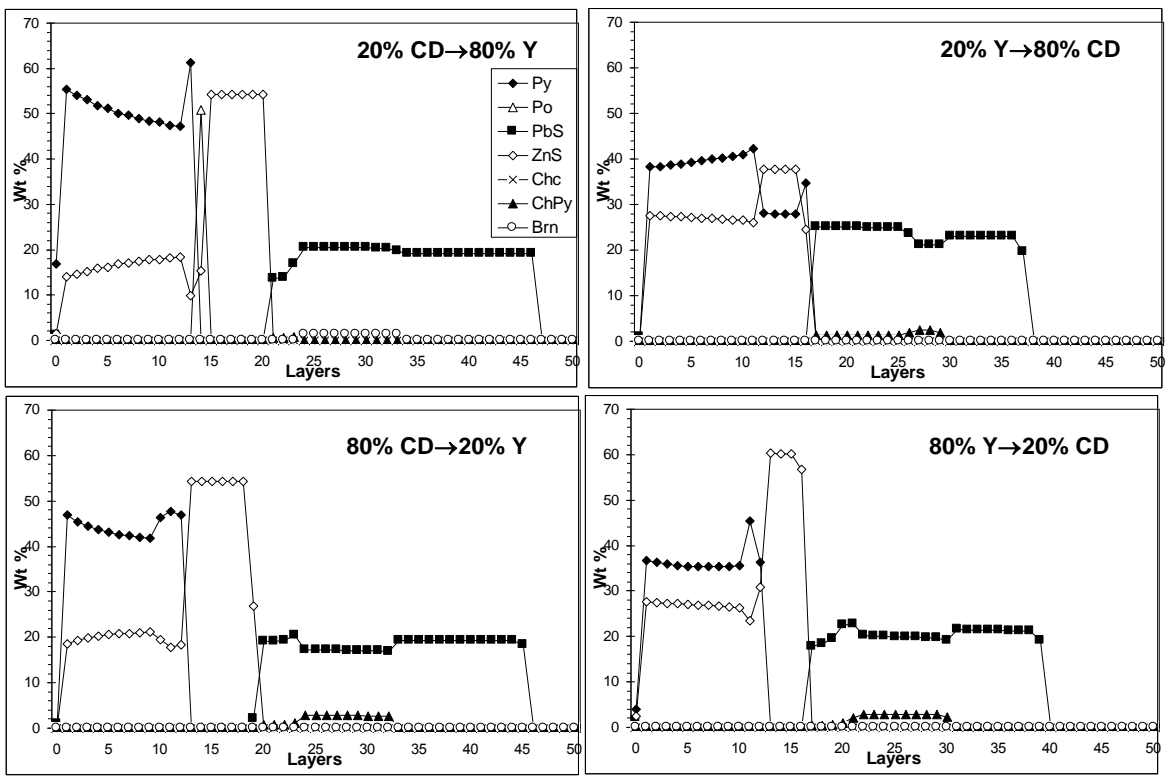

Fig. 5. Structure of filling veins at the $200^{\circ} \mathrm{C}$ level in accordance with the assumed model of the mobilization zone with the order corresponding to that of Fig.4 (Legend: Py - pyrite; Po - pyrrhotite; PbS - galena; ZnS - sphalerite; Chc - chalcocite; ChPy chalcopyrite; Brn - bornite).

The system of parallel reactors in the mobilization zone was calculated for two cases: predominance of fluid resulting from reaction with either granite or crystalline schist (i.e. $80 \% \mathrm{Y}$ and $20 \% \mathrm{CD}$ and vice versa). According to the first case, mineral assemblages formed are typical of the deposits of the area and correspond to the " $\mathrm{CD} \rightarrow \mathrm{Y}$ " or $\mathrm{Y}$ model described above. Mineral assemblages formed according to the second case correspond to the " $\mathrm{Y} \rightarrow \mathrm{CD}$ " model.

\section{Conclusions}

Geochemical evaluation and thermodynamic modeling of hydrothermal veining of the lead-zinc deposit of the Sadon mining district (North Caucasus, Ossetia, Russia) demonstrate that ore element behavior depends on extent of water/rock interaction. It is established through modeling that both types of prevailing rocks of the area are involved in the ore-formation, i.e. the Paleozoic granites that are the main ore-hosting rocks at the majority of vein deposits, and the Precambrian schists that are specific only to the Dzhimidon deposit. The source of ore components tends to be complex and includes host rocks in variable proportions which could be characterized by REE distribution in ores. Thermodynamic models calculated for systems with complex source of ore components revealed that simulation of mineral assemblages typical of real deposits is impossible for fluids resulted from reaction with dominated crystalline schist, recorded for more ore samples based on REE distribution. Therefore, Precambrian metamorphic rocks were involved in the ore-formation in a more limited way, either only for short episodes during of evolution of hydrothermal system or at short intervals in updip portions of the veins.

This work was supported by Russian Foundation for Basic Research, project number17-05-00244.

\section{References}

1. A.I. Tugarinov, E.V. Bibikova, et al. Geokhimiya. 8, 1156-1163 (1975)

2. M.V. Borisov, D.A. Bychkov, and Yu.V.Shvarov. Geochem.Int. 44, 11, 1129-1147 (2006)

3. M.V. Borisov. Geochem.Int. 41, suppl. 2, S145-S312 (2003)

4. M.V. Borisov, M.M. Volkova, D.A. Bychkov. Geochem.Int. 54, 4, 346-361 (2016)

5. Yu.V. Shvarov. Geochem.Int. 46, 8, 834-839 (2008)

6. Yu.V. Shvarov. Geochem.Int. 37, 6, 571-576 (1999) 